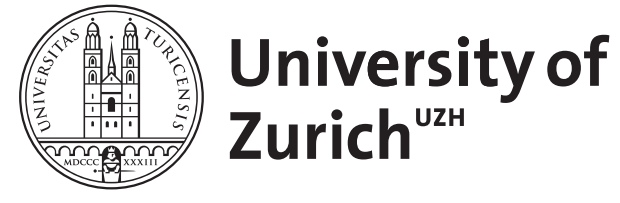
Archive

University of Zurich

University Library

Strickhofstrasse 39

CH-8057 Zurich

www.zora.uzh.ch

Year: 2008

\title{
Therapeutic antibodies in multiple sclerosis
}

Goebels, Norbert ; Becher, Burkhard

DOI: https://doi.org/10.1159/000109931

Posted at the Zurich Open Repository and Archive, University of Zurich

ZORA URL: https://doi.org/10.5167/uzh-14143

Journal Article

Published Version

Originally published at:

Goebels, Norbert; Becher, Burkhard (2008). Therapeutic antibodies in multiple sclerosis. Neurodegenerative Diseases, 5(1):5-7.

DOI: https://doi.org/10.1159/000109931 


\title{
Therapeutic Antibodies in Multiple Sclerosis
}

\author{
Norbert Goebels Burkhard Becher \\ Neurologische Klinik, Universitätsspital Zürich, Zürich, Switzerland
}

Multiple sclerosis (MS) is the most common chronic inflammatory disease of the central nervous system (CNS). MS commonly strikes young adults, exposing them to an uncertain future dimmed by neurological impairment. In spite of immense research efforts in the last decades, there is still no cure for MS. In fact, the cause of MS, leading to variable degrees of inflammation, demyelination and axonal damage in the CNS, is enigmatic. While a strong genetic predisposition is established, environmental factors, possibly infectious agents encountered during childhood and puberty, seem to play an equally important role.

Until the early 1990s, immunosuppressive agents like azathioprine were the mainstay of MS treatment. Since then, MS therapy has dramatically changed. New immunobiological findings and pathophysiological concepts as well as advances in biotechnology lead to the identification of a variety of potential therapeutic targets. Improvements in clinical trial design and the development of magnetic resonance imaging have made it possible to objectively quantify the therapeutic benefit of new treatment modalities in a disease as heterogeneous and unpredictable as MS. Also, both society and health insurances have recognized that prevention or delay of neurological impairment in MS patients is important and may be cost effective even in spite of the high prices of modern immunomodulatory drugs, when taking into account the reduced quality of life and the enormous secondary costs due to disability. This in return has made it worthwhile for pharmaceutical companies to invest in the develop- ment of ever more effective drugs for the treatment of MS.

The first immunomodulatory agents to benefit from the development mentioned above, interferon- $\beta$ (Avon$\mathrm{ex}^{\circledR}$, Betaferon/Betaseron ${ }^{\circledR}$, Rebif $\left.{ }^{\circledR}\right)$ and glatiramer acetate $\left(\right.$ Copaxone $\left.{ }^{\circledR}\right)$, have been on the market for more than a decade now and are established, safe, yet only mildly effective treatments for MS. They reduce the frequency of new relapses by $30-40 \%$, and their effect on disease progression has remained controversial. Additionally, the necessity to self-inject these drugs in intervals between once daily $\left(\right.$ Copaxone ${ }^{\circledR}$ ) to once weekly $\left(\right.$ Avonex $\left.{ }^{\circledR}\right)$, as well as common side effects, such as flu-like symptoms and injection site reactions, limit patient compliance to some degree. Numerous researchers have demonstrated that both interferon- $\beta$ and glatiramer acetate exert 'pleiotropic effects' on the immune system and the CNS, while essentially leaving the question unanswered as to which of these multiple modes of action are central in treating MS.

In contrast, antibodies, in principal a natural component of the immune system, constitute a different kind of therapeutic agents, which can interact with precisely defined targets. This issue of Neurodegenerative Diseases focuses on the role of antibodies as a therapy for MS. The article by Soelberg Sorensen is dedicated to a truly 'natural' human antibody preparation: these so-called 'intravenous immunoglobulins' are polyclonal human antibodies isolated from the pooled plasma of thousands of human donors. Intravenous immunoglobulins contain the normal humoral immune repertoire and have been

\section{KARGER}

Fax +4161306 1234

E-Mail karger@karger.ch

www.karger.com
(C) 2008 S. Karger AG, Basel

$1660-2854 / 08 / 0051-0005 \$ 24.50 / 0$

Accessible online at:

www.karger.com/ndd
Prof. Norbert Goebels

Neurologische Klinik, Universitätsspital Zürich

Frauenklinikstrasse 26

CH-8091 Zürich (Switzerland)

Tel. +41 4425555 15, Fax +41 4425543 80, E-Mail norbert.goebels@usz.ch 
Fig. 1. Recombinant techniques allow different extents of 'humanization' of mAbs (http://www.medarex.com/Development/ Evolution.htm). CDR = Complementarity determining regions.

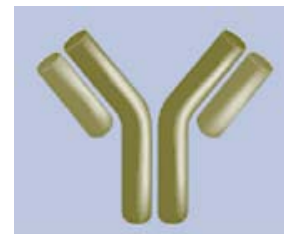

Murine

$00 \%$ mouse protein

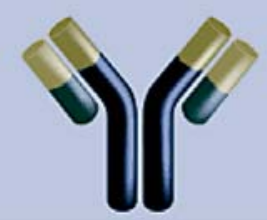

Chimeric

$33 \%$ mouse protein

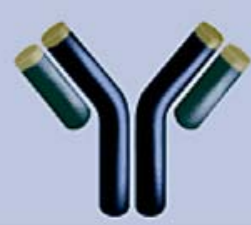

CDR-grafted

5-10\% mouse protein

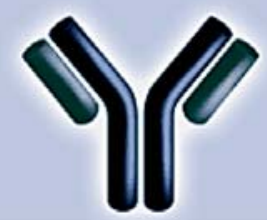

UltiMAb antibodies $100 \%$ human protein

Table 1. Therapeutic antibodies in MS

\begin{tabular}{llllll}
\hline $\begin{array}{l}\text { Generic } \\
\text { name }\end{array}$ & Brand name & Antibody type & $\begin{array}{l}\text { Target } \\
\text { molecule }\end{array}$ & Target cell & $\begin{array}{l}\text { Stage of development for treating } \\
\text { MS }\end{array}$ \\
\hline IVIG & several & human, natural, polyclonal & N/A & N/A & used as second-line treatment of MS \\
\hline Natalizumab & Tysabri $^{\circledR}$ & $\begin{array}{l}\text { humanized, recombinant, } \\
\text { monoclonal }\end{array}$ & $\alpha 4$-integrin & activated lymphocytes & licensed for treatment of MS \\
\hline Alemtuzumab & Campath-1H ${ }^{\circledR}$ & $\begin{array}{l}\text { humanized, recombinant, } \\
\text { monoclonal }\end{array}$ & CD52 & $\begin{array}{l}\text { T cells, B cells, mono- } \\
\text { cytes, macrophages }\end{array}$ & clinical trials \\
\hline Daclizumab & Zenapax ${ }^{\circledR}$ & $\begin{array}{l}\text { humanized, recombinant, } \\
\text { monoclonal }\end{array}$ & CD25 & T cells & clinical trials \\
\hline Rituximab & Rituxan ${ }^{\circledR}$ & $\begin{array}{l}\text { chimeric, recombinant, } \\
\text { monoclonal }\end{array}$ & CD20 & B cells & clinical trials \\
\hline Infliximab & Remicade ${ }^{\circledR}$ & $\begin{array}{l}\text { chimeric, recombinant, } \\
\text { monoclonal }\end{array}$ & TNF- $\alpha$ & N/A & $\begin{array}{l}\text { approved for the treatment of } \\
\text { rheumatoid arthritis; discontinued } \\
\text { for the treatment of MS }\end{array}$ \\
\hline CNTO-1275 & N/A & $\begin{array}{l}\text { human, recombinant, } \\
\text { monoclonal }\end{array}$ & IL-12/23 p40 & N/A & preclinical \\
\hline ch5D12 & N/A & $\begin{array}{l}\text { chimeric, recombinant, } \\
\text { monoclonal }\end{array}$ & CD40 & $\begin{array}{l}\text { antigen-presenting } \\
\text { cells }\end{array}$ & preclinical
\end{tabular}

Overview of antibody-based therapeutics used or evaluated for the treatment of MS. IVIG = Intravenous immunoglobulins; N/A = not applicable; TNF- $\alpha=$ tumor necrosis factor- $\alpha$; IL = interleukin.

established as effective therapy for several human autoimmune conditions. Yet, for a number of reasons, they have remained a 'second-line' option for the treatment of relapsing-remitting MS.

The remaining articles deal with recent developments of monoclonal antibody (mAb) therapies. mAbs, uniform in their molecular make-up, have defined specificities and are thought to constitute a particularly promising class of bioactive molecules. Traditionally, mAbs are generated from rodents after immunization with a target molecule of choice. B cells from immunized animals are immortalized by fusion with myeloma cells creating 'hybridomas', which are then cloned and tested for the specificity of their secreted antibodies [1]. Using this ap- proach, researchers have generated $m A b s$ against a plethora of different target antigens, which now serve as ubiquitous tools in research laboratories around the world. However, as therapeutic agents, common mAbs with a rodent molecular buildup have been shown to possess limited applicability in humans. Due to their structural differences to human antibodies they are - when injected repeatedly - recognized as foreign proteins and often neutralized by the recipient's immune system. In order to circumvent this neutralizing immune response, biopharmaceutical companies have undertaken great efforts to 'humanize' rodent antibodies by using molecular tools: in a first step, immunoglobulin (Ig) variable genes from rodent hybridomas are fused with human IgG constant 
region genes and expressed recombinantly as 'chimeric' antibodies. These antibodies are far less immunogenic, but can still elicit immune responses. Alternatively, the complementarity determining regions of the antibody, which are most relevant for the antigen recognition, can be grafted into a human IgG backbone, creating 'humanized' antibodies. Recent developments allow the generation of fully human $\mathrm{mAbs}$ by either using transgenic mice carrying human Ig genes [2] or by cloning antibodies directly from the human immune repertoire [3].

In order to influence the immune system, mAbs can act by neutralizing soluble factors like cytokines, as in the case of infliximab or CNTO-1275 (table 1). Alternatively, they can alter immune cell functions by binding to cell surface molecules, as in the case of natalizumab, daclizumab and ch5D12. In contrast, alemtuzumab and rituximab alter the function of the immune system by depleting whole subpopulations of immune cells.

In their article, Engelhardt and Kappos describe the preclinical and clinical development of natalizumab $\left(\right.$ Tysabri ${ }^{\circledR}$ ), which has recently been (re)licensed for the treatment of patients with severe forms of relapsing MS. Clinical trials have demonstrated that natalizumab is currently one of the most efficacious treatments for this type of MS. Natalizumab interferes with lymphocyte extravasation, thus limiting their contribution to local inflammatory processes. To which extent the 'beneficial immunosurveillance' is affected as well has been under close observation since 3 patients developed progressive multifocal leukencephalopathy while being treated with natalizumab in combination with other agents influencing the immune system.
Most of the other mAbs described in this issue of $\mathrm{Neu}$ rodegenerative Diseases are currently at different stages of preclinical or clinical development with regard to treating MS. Some of these mAbs, such as daclizumab, described in the article by R. Martin, as well as rituximab and alemtuzumab, discussed by Jones and Coles, are already licensed for the treatment of certain types of hematological malignancies. Infliximab, 1 of 3 currently available agents which neutralize the action of tumor necrosis factor- $\alpha$, a key molecule in many inflammatory processes, is a very potent drug for the therapy of patients with severe forms of rheumatoid arthritis. Interestingly, although tumor necrosis factor- $\alpha$-neutralizing agents, elaborated by Taoufik and colleagues, also showed promising effects in a common animal model of MS, experimental autoimmune encephalomyelitis, these agents completely failed in early trials with MS patients and actually increased disease activity. In their article, t'Hart and colleagues describe preclinical studies with mAbs influencing antigen presentation (CNTO-1275) and lymphocyte polarization (ch5D12).

In summary, this issue of Neurodegenerative Diseases emphasizes the enormous potential of antibody-based therapies for the treatment of MS and other immune-mediated diseases. However, even the selective targeting of a single immune-relevant molecule can apparently induce effects completely unforeseeable in both animal models and patients with different diseases. Such unexpected adverse effects stress the need to further study both basic mechanisms of immunomodulation in conjunction with well-conducted clinical trials.

\section{References}

Therapeutic Antibodies in MS
1 Köhler G, Milstein C: Continuous cultures of fused cells secreting antibody of predefined specificity. Nature 1975;256:495497.

2 Lonberg N: Human antibodies from transgenic animals. Nat Biotechnol 2005;23:11171125 .
3 Traggiai E, Becker S, Subbarao K, Kolesnikova L, Uematsu Y, Gismondo MR, Murphy BR, Rappuoli R, Lanzavecchia A: An efficient method to make human monoclonal antibodies from memory B cells: potent neutralization of SARS coronavirus. Nat Med 2004;10:871-875. 